\title{
RISK MANAGEMENT IN CONSTRUCTION ENTERPRISES IN ŚLĄSKIE AND MALOPOLSKIE VOIVODSHIPS IN POLAND
}

\author{
Piotr TWOREK ${ }^{1 *}$, Józef MYRCZEK ${ }^{2}$ \\ ${ }^{1}$ University of Economics in Katowice; piotr.tworek@ue.katowice.pl, ORCID: 0000-0002-2871-2902 \\ ${ }^{2}$ University of Bielsko-Biała; jmyrczek@ath.bielsko.pl, ORCID: 0000-0002-9351-1410 \\ * Correspondence author
}

Purpose: The publication is empirical in its character. The key purpose of the paper is to outline and discuss the results of the empirical research into risk in construction activities carried out by the surveyed contractors in Poland. The paper focuses, in particular, on the use of methods, techniques and tools by construction enterprises from Śląskie and Małopolskie voivodships to respond to the risks they encounter.

Design/methodology/approach: The empirical research was conducted in form of a questionnaire interview. The research tools were developed based on in-depth studies of the scholarly literature (theory-cognitive dimension of the research). The paper also uses the methods of synthesis and deduction. In their discussions the authors draw on their own knowledge and experience which they have acquired over many years spent on researching risks faced by a wide range of organisations.

Findings: The presented research findings provide the empirical verification of the theoretical background derived from the literature in the field.

Research limitations/implications: The paper presents only the selected results of the empirical studies. These research findings concern specific categories of construction risk, which is regarded as a scientific and research category.

Practical implications: The paper presents practical knowledge (utilitarian dimension of science) which has been verified empirically in the conducted research. This knowledge is referred to in the scholarly literature as Construction Risk Management (CRM).

Originality/value: The empirical studies present an up-to-date status of the knowledge and awareness as demonstrated by the construction contractors participating in the survey. The research findings are presented for the purpose specified in the paper.

Keywords: Enterprise risk management, risk response, construction risk, construction enterprise, survey research.

Category of the paper: Research paper. 


\section{Introduction}

To come up with the right risk responses individuals responsible for risk management in the construction industry need the right amount of knowledge. The importance of this issue has led to numerous attempts at finding new solutions which could possibly be implemented in this respect. The scholarly literature clearly places an emphasis on that as well. In business practice of major construction companies operating on the Polish market, however, risk management tends to be limited to arranging insurance to cover construction and assembly activities they carry out, as this seems to be the most common method of financing risks in economic activities (Tworek, 2013). Important as this may be, insurance cover is just one of many possible risk responses, which are referred to in the currently available sources of knowledge, such as the concept of Construction Risk Management (CRM) (Palmer et al., 1996; Bunni, 2003). How should construction risks be responded to, then? Which methods, techniques and tools can be used for that? These are the questions the paper attempts to address. The aim of this paper is to outline the problems of risk responses in the field of construction activities carried out by specialised enterprises from Śląskie and Małopolskie voivodships in Poland. The key aim of the publication is, first of all, to outline and discuss the results of the empirical research into risk in construction activities carried out by the surveyed contractors. The empirical studies were conducted in 2016 among part-time students of Construction and Environmental Engineering at Akademia Techniczno-Humanistyczna in Bielsko-Biała (University of BielskoBiała), who were also employed in the companies surveyed. The research covered 31 respondents, who anonymously completed two questionnaires. The paper also provides the results of the research done in 2015 among 29 contractors operating in the selected poviats of Śląskie voivodship (Bielsko-Biała, Żywiec, Czechowice-Dziedzice, Tychy, Jastrzębie Zdrój, Wodzisław Śląski and Rybnik) (Myrczek et al., 2015) and partially draws from the empirical studies conducted among the major construction contractors on the Polish market, including, in particular, companies listed on the stock exchange, in the years of 2010-2012 (Tworek, 2013). Although the paper is empirical in its character its contents are embedded in the theory of risk management in the construction industry. The main research method has been a questionnaire interview. Another technique used in the studies on construction risk has been face-to-face interview. The studies required a prior in-depth review of the literature on the subject. The paper focuses on the methodical aspects of risk management in organisations which specialise in construction and assembly activities.

This publication is a follow-up on the research into risks encountered by Polish construction companies, conducted by the authors (Tworek, 2012, 2013; Myrczek et al., 2015, 2020; Myrczek, and Tworek, 2019; Kosmalski, and Myrczek, 2019). In broad terms, the aim of a series of publications focusing on this topic is an attempt to find an answer to the following question: How should risk be managed by construction contractors operating on the Polish market? 


\section{Responses to risk as an element of risk management process in construction - theoretical approach, survey research}

There are many scientific publications on how to manage risks in the construction industry (Flanagan, and Norman, 1993; Edwards, 1995; Boothroyd, and Emmett, 1996; Godfrey, and Halcrow, 1996; Palmer et al., 1996; Loosemore et al., 2006; Smith et al., 2006; BurtonshawGunn, 2009; Wang, et al., 2004; Serpell et al., 2017; Hoseini et al., 2019). Irrespective of the views expressed by specific authors, however, participants of investment and construction processes are almost invariably required to develop their own individual risk management plans, due to the unique character of construction risks they need to tackle. The development of a risk response plan is a key task within the risk management process as this plan sets out the methods to be used to address potential risk-bearing occurrences (Kosmalski, and Myrczek, 2019). Before construction risk responses may be planned, though, risks need to be clearly identified. A construction contractor's failure to identify and then evaluate risks may lead to the selection of an inappropriate risk response method, technique or tool. Construction risk management as such is a complex process, spanning through the stages of risk identification, quantification and response (Flanagan, and Norman, 1993), which follow in this order. These are the three key phases of risk management but may be supplemented by monitoring and control over the execution of the stages. Whatever the concept of risk management, however, if risks are to be addressed by a construction company, suitable risk prevention methods, techniques and tools must first be chosen. At the same time, risk response itself is a sub-process which is part of the overall risk management process in the construction industry.

Construction enterprises respond to risks in the following ways:

- they eliminate risks by introducing changes and modifications to e.g. a project, technology or delivery etc.,

- they transfer risk, i.e. pass on possible costs of losses, which may arise, to another party to the construction project implementation process,

- they mitigate risk by e.g. arranging construction and assembly insurance,

- they absorb risk, which means that a contractor accepts the risk (Kosecki, and Madyda, 1996).

These are the main ways of responding to construction risks, provided by the scholarly literature (Flanagan, and Norman, 1993; Kosecki, and Madyda, 1996; Godfrey, and Halcrow, 1996; Boothroyd, and Emmett, 1996; Glavinich, 2008; Sawczuk, 2004; Zuo, and Zhang, 2018). According to the studies on modern risk management strategies in organisations a number of risk responses tend to be used simultaneously or even hybrid strategies are devised in order to optimise risk by its mitigation and transfer, while retaining part of it (Edwards, and Bowen, 2005). An extreme way of handling risk in the construction industry is making a decision not to perform high-risk works. The results of the empirical studies from 2016, however, show that 
$47 \%$ of contractors agree to perform even high risk construction projects (Myrczek, and Tworek, 2019; Myrczek et al., 2020). In the research the respondents indicated some reasons for taking up risky construction projects. These included: ensuring healthy cashflow (4 contractors), maintenance of high turnover figures (2 contractors), financial reasons ( 2 contractors), the belief that risk can be eliminated ( 2 contractors), an investment project with a relatively late delivery date (1 contractor), a high value investment project ( 1 contractor), the prestige given by the project - the renovation of Auschwitz ( 1 contractor), the need to perform a given task ( 1 contractor), an investment project with highly filled order portfolio ( 1 contractor), poor market conditions - a small number of tenders (1 contractor), good construction practice ( 1 contractor), a big number of employees ( 1 contractor), more lucrative works ( 1 contractor), the company's position on the market (1 contractor), the investor's insolvency ( 1 contractor), technical documentation (1 contractor). Such arguments allow us to get a better understanding of the motives behind construction contractors' practical decisions, although only $9 \%$ of them agreed to absorb all the risk (Myrczek, and Tworek, 2019; Myrczek et al., 2020). As many as $38 \%$ of the contractors eliminate risks, $34 \%$ of the respondents mitigate risks, while $13 \%$ of them transfer risk onto other participants of investment and construction processes (Myrczek, and Tworek, 2019; Myrczek et al., 2020). For the sake of comparison - no one from among the surveyed major construction and assembly companies operating on the Polish market stated that they absorb risk, while $54 \%$ of them eliminate risks, $11.4 \%$ of the respondents transfer risks and $34.6 \%$ of the biggest contractors limit construction risks (Tworek, 2013). Irrespective of a risk management strategy described in the scholarly literature (Young, and Tippins, 2001) and of specific practices implemented by a given organisation, every contractor must carefully differentiate among methods, techniques and tools which are available for them to handle their construction risks. The key role here is played by the identification of risks which have to be managed.

\section{The use of response methods, techniques and tools in the activity of construction enterprises in the light of the empirical research}

The detailed results of the empirical research concern such sub-categories of construction risks which refer to the measures undertaken by contractors in order to prevent risks related to personnel, construction site documentation, the construction process itself (technological process, technical risk) as well as organisation and management, finance and the environment in which these enterprises operate. What needs to be emphasised here is the fact that such arbitrary division results from the key areas where risks occur in the operations of construction and assembly enterprises, which is yet another argument for the utilitarian dimension of knowledge related to these issues. The general classification of construction risk categories 
given in the theory has a less important role here. When looking at the general theory of economics, where every organisation operates in an environment, exogenous risk, i.e. risk related to the surroundings in which a given contractor conducts its business, should theoretically come first. What measures are then undertaken by the surveyed contractors in order to prevent risks related to their environment? The respective findings are given in Table 1.

\section{Table 1.}

Risks related to the contractor's environment: risk responses

\begin{tabular}{|c|l|c|}
\hline Item & \multicolumn{1}{|c|}{ What measures do you take to counteract risks related to your environment? } & Percentage \\
\hline 1 & Continuous monitoring of your (macro- and micro) environment & $23 \%$ \\
\hline 2 & Additional references from new subcontractors & $42 \%$ \\
\hline 3 & Business intelligence regarding business partners (investors and subcontractors etc.) & $35 \%$ \\
\hline 4 & Engaging reliable designers and subcontractors & $58 \%$ \\
\hline 5 & Keeping up-to-date with legal regulations & $26 \%$ \\
\hline 6 & Maintaining good relations with local authorities (public officials) & $52 \%$ \\
\hline 7 & Defining political risk & $0 \%$ \\
\hline
\end{tabular}

Note. The respondents were permitted to indicate more than one reply, therefore the total may exceed 100\%. Source: based on: Tworek, 2013.

The research shows that the key aspect of risk response is engaging reliable designers and trustworthy subcontractors, as well as maintaining good relations with local authorities (public officials) - over $50 \%$ of the surveyed contractors indicated these items. In practical business these are the elements of the contractors' closest environment. Much less importance was attached to macro- and micro-environment issues ( $23 \%$ of the contractors), including the need to keep up-to-date with legal regulations ( $26 \%$ of the contractors). None of the responding contractors indicated the political risk. How do these results compare with the risk management issues which are easier for construction companies to control? The respective findings are presented in Tables 2-5.

Table 2.

Risks related to the contractor's personnel: risk responses

\begin{tabular}{|c|l|c|}
\hline Item & \multicolumn{1}{|c|}{ What measures do you take to counteract risks related to personnel? } & Percentage \\
\hline 1 & Creating a risk management unit in a company & $6 \%$ \\
\hline 2 & (Continuous) risk management training for company managers & $32 \%$ \\
\hline 3 & Employing in-house risk specialists (risk managers) & $61 \%$ \\
\hline 4 & OHS training for manual workers (compliance with work discipline) & $65 \%$ \\
\hline 5 & Appropriate staff supervision on construction sites & $42 \%$ \\
\hline 6 & $\begin{array}{l}\text { Additional courses and training for manual workers in the area of technical knowledge } \\
\text { for the construction industry }\end{array}$ & $39 \%$ \\
\hline 7 & Additional courses and training for construction site managers (contracts) & $19 \%$ \\
\hline 8 & Delegating risk management tasks to experts & $42 \%$ \\
\hline 9 & $\begin{array}{l}\text { Ensuring appropriate and skilled workforce for the performance of the construction } \\
\text { project }\end{array}$ & $61 \%$ \\
\hline
\end{tabular}

Note. The respondents were permitted to indicate more than one reply, therefore the total may exceed 100\%. Source: based on: Tworek, 2013. 
Table 3.

Risks related to construction site documentation: risk responses

\begin{tabular}{|c|l|c|}
\hline Item & \multicolumn{1}{|c|}{$\begin{array}{c}\text { What measures do you take to counteract risks related to construction site } \\
\text { documentation? }\end{array}$} & Percentage \\
\hline 1 & Entering into cost reimbursement contracts & $26 \%$ \\
\hline 2 & Contractual clauses offering security in case of cost increase & $32 \%$ \\
\hline 3 & Security against exchange rate fluctuations (when cooperating with foreign parties) & $10 \%$ \\
\hline 4 & Security in the case delivery dates for construction projects need to be changed & $29 \%$ \\
\hline 5 & Final delivery date of a construction project & $19 \%$ \\
\hline 6 & Incorporation of special risk clauses & $29 \%$ \\
\hline 7 & Shortest possible guarantee and warranty periods & $48 \%$ \\
\hline 8 & Detailed description of force majeure risk & $13 \%$ \\
\hline 9 & Detailed provisions on liquidated damages & $48 \%$ \\
\hline 10 & Detailed terms for withdrawal from or cancellation of a contract & $32 \%$ \\
\hline 11 & Thorough review of construction site documentation for its completeness & $39 \%$ \\
\hline 12 & Securing construction projects by obtaining central and local government guarantees & $10 \%$ \\
\hline 13 & Transferring risk to subcontractors (within the scope of their operations) & $16 \%$ \\
\hline 14 & $\begin{array}{l}\text { Where risk in its entirety cannot be transferred to an investor, a proposal to equally } \\
\text { share risk between an ordering party (a customer) and a contractor }\end{array}$ & $10 \%$ \\
\hline 15 & $\begin{array}{l}\text { Documenting all irregularities and negative behaviours on the part of other participants } \\
\text { of an investment project }\end{array}$ & $23 \%$ \\
\hline 16 & Submitting a contract for detailed legal review before signing it & $39 \%$ \\
\hline 17 & Creating risk documentation (risk lists, risk sheets) & $0 \%$ \\
\hline
\end{tabular}

Note. The respondents were permitted to indicate more than one reply, therefore the total may exceed 100\%. Source: based on: Tworek, 2013.

Table 4.

Risks related to a construction performance process, including a technological process, and technical risk; risks related to company organisation and management: risk responses

\begin{tabular}{|c|l|c|}
\hline Item & $\begin{array}{l}\text { What measures do you take to counteract risks related to a construction } \\
\text { performance process (technological process, technical risk) and organisation and } \\
\text { management? }\end{array}$ & Percentage \\
\hline 1 & \multicolumn{1}{|c|}{ Using tried and tested technologies } & $61 \%$ \\
\hline 2 & Using premium quality materials which are environmentally friendly & $35 \%$ \\
\hline 3 & Lease of reliable machines and equipment, with required attestations & $35 \%$ \\
\hline 4 & Additional security for force majeure events (e.g. extra wind protection) & $19 \%$ \\
\hline 5 & $\begin{array}{l}\text { Requiring additional expert opinions on subsurface conditions (from an ordering } \\
\text { party) }\end{array}$ & $10 \%$ \\
\hline 6 & $\begin{array}{l}\text { Effective control of a project performance process (regular checks of works } \\
\text { performed, funds spent and delivery time) }\end{array}$ & $32 \%$ \\
\hline 7 & $\begin{array}{l}\text { Including an investor and subcontractors in planning and designing of the scope of } \\
\text { works }\end{array}$ & $29 \%$ \\
\hline 8 & $\begin{array}{l}\text { When performing big investment projects teaming up with other contractors by } \\
\text { establishing shared risk consortia }\end{array}$ & $16 \%$ \\
\hline 9 & Providing and controlling infrastructure around the construction site & $35 \%$ \\
\hline 10 & $\begin{array}{l}\text { Supporting the construction performance process with activities aimed to optimise } \\
\text { project-related processes, combined with the use of appropriate optimisation } \\
\text { techniques (e.g. PERT) }\end{array}$ & $0 \%$ \\
\hline 11 & Implementing an effective logistics system in a company & $23 \%$ \\
\hline 12 & Trying to identify risk factors before starting a project performance process & $23 \%$ \\
\hline 13 & Participating in all 'safe" tenders in the region & $16 \%$ \\
\hline 14 & Using appropriate computer software to support a construction planning process & $23 \%$ \\
\hline 15 & When participating in tenders not offering prices which are below safe levels & $35 \%$ \\
\hline 16 & Ensuring reliable means of transport & $32 \%$ \\
\hline 17 & Collecting risk information (on an ongoing basis) from databases & $10 \%$ \\
\hline 18 & Securing a construction site against vandalism and theft & $35 \%$ \\
\hline & & \multicolumn{1}{|c|}{ and } \\
\hline
\end{tabular}


Cont. table 4.

\begin{tabular}{|c|l|c|}
\hline 19 & $\begin{array}{l}\text { Intensifying such activities as: field inspections, frequent interviews with key project } \\
\text { participants, etc. }\end{array}$ & $19 \%$ \\
\hline 20 & Simulating foreseeable situations and devising risk prevention schemes & $6 \%$ \\
\hline 21 & Implementing schemes, action plans and procedures in case of risk & $10 \%$ \\
\hline 22 & Avoiding high risk investment projects & $16 \%$ \\
\hline 23 & Implementing an ISO quality system in a company & $16 \%$ \\
\hline 24 & Performing a bigger number of construction projects which are less risky & $16 \%$ \\
\hline 25 & Diversification of a company's activities (hotels for workers etc.) & $6 \%$ \\
\hline
\end{tabular}

Note. The respondents were permitted to indicate more than one reply, therefore the total may exceed 100\%. Source: based on: Tworek, 2013.

Table 5.

Risks related to the contractor's finance: risk responses

\begin{tabular}{|c|l|c|}
\hline Item & \multicolumn{1}{|c|}{ What measures do you take to counteract risks related to finance? } & Percentage \\
\hline 1 & Cooperation with a well-established bank (funds provider) & $61 \%$ \\
\hline 2 & Obtaining a payment guarantee from investors & $35 \%$ \\
\hline 3 & Financial monitoring (object- and subject-related) during the project performance & $35 \%$ \\
\hline 4 & Calculating cost-related risk, using such methods as MERA & $19 \%$ \\
\hline 5 & Creating special reserves for risks & $10 \%$ \\
\hline 6 & Cooperating with a successful debt collection company & $32 \%$ \\
\hline 7 & Arranging polices such as CAR and EAR (continuous insurance coverage) & $29 \%$ \\
\hline
\end{tabular}

Note. The respondents were permitted to indicate more than one reply, therefore the total may exceed 100\%. Based on: Tworek, 2013. Source: Myrczek, and Tworek, 2019; Myrczek et al., 2020.

When looking at Tables 2-5 we can see the extent to which specific methods, techniques and tools are used by contractors to respond to the construction risks they encounter. In the vast majority of cases these are the types of risks which may almost entirely be controlled by a given construction company, i.e. they belong to the category of indigenous risks of an organisation. The literature divides risks here into specific ones and systematic ones (Godfrey, and Halcrow, 1996; Boothroyd, and Emmett, 1996; Young, and Tippins, 2001). A risk which remains beyond a contractor's control is a systematic risk (Table 1), while Tables 2-5 concern specific risks which have to be tackled.

The specific character of business conducted by construction and assembly companies makes construction risk management a challenge to deal with. This concerns, first of all, such risk categories as force majeure, the occurrence of which may never be fully predicted. $19 \%$ of the respondents use additional measures to protect themselves against force majeure, e.g. extra wind covers. In addition, construction sites, where construction and assembly companies operate, require risk mitigating measures which differ from the ones undertaken by entities with other business profiles, e.g. other producers or service providers. This can easily be seen when analysing the results given in Tables 3 and 4 . The issues comprised in Tables 1 , 2 and 5, in turn, are a bit more general in their character, as they refer to the theory of economics and management sciences (Drucker, 1964). In business practice it means that the methods, techniques and tools outlined in Tables 1, 2 and 3 may apply to almost any organisation. For instance, the establishment of a risk management unit (Table 2) is an option that may be applicable both to public organisations and private entities. The research done in 2015 shows that as many as $51 \%$ of the companies surveyed have not appointed any specific person to be 
directly responsible for risk management (Myrczek et al., 2015). Nevertheless, during face-toface interviews, when taking a closer look at the risk management issues in the construction industry, the respondents tended to stress the need to change their attitude to practical risk management (Myrczek et al., 2015). For the sake of comparison, a mere 8\% of the largest construction and assembly companies operating in the Polish market have set up risk management units and employed their own risk management specialists (Tworek, 2013). The key reasons behind this, as indicated by the contractors surveyed in 2016, include the belief that the risk they face is not high enough to hire a person (set up a unit) to specifically deal with it ( $25 \%$ of the contractors) and that their peer companies do not employ any specialists in this field either $-31 \%$ of the contractors (Myrczek, and Tworek, 2019; Myrczek et al., 2020). None of the contractors, however, stated that construction risk categories they face cannot be fully identified (Myrczek, and Tworek, 2019; Myrczek et al., 2020).

\section{Conclusion}

The empirical studies the paper refers to may lead to the conclusion that specific risk management methods, techniques and tools vary in terms of their popularity in construction companies. The research conducted in 2016 focused on the selected construction enterprises only and was also limited geographically as it did not cover the entire territory of Poland. In the 2015 studies the respondents admitted that they were acquainted with risk management issues because they dealt with risk management in their own work, rather than studying risk management theories during their education (Myrczek et al., 2015). They often confessed that their understanding of a risk management system was somewhat different to the way the issue used to be presented in the professional literature (Myrczek et al., 2015). Their views are illustrated by the contents of Tables 3 and 4, which are based on highly specialised knowledge. Tables 1, 2 and 5 present the issue from the point of view of a today's engineer - manager who is capable of managing the construction performance process but also managing an organisation, such as a construction business. We can also see that construction risk is a cross-disciplinary research category comprising the elements of technical, business and legal knowledge.

Irrespective of that, the risk management methods, techniques and tools referred to in the paper and used to respond to risks in the operations caried out by construction contractors seem equally important. The review of the literature on the subject shows that risk management methods should be used in a comprehensive and complementary way. Which risk response is selected depends predominantly on the type of a construction project that a company is involved in. A project portfolio that a given construction enterprise has is also important as well as their financial standing and the funds they have available to finance risk. Consequently, 
the contractors surveyed are either ready to retain risk or decide to transfer it to an insurer or another participant of an investment and construction process. In general, contractors in Poland are the stakeholders who tend to bear risk (Tworek, 2013). This is due to the features of the Polish construction and assembly market. Out of all the contractors surveyed from Śląskie and Małopolskie voivodships, as many as $38 \%$ of them bear all the risk, while only $9 \%$ of them transfer most of the risk to investors (Myrczek, and Tworek, 2019; Myrczek et al., 2020).

\section{References}

1. Boothroyd, C., and Emmett, J. (1996). Risk Management: A practical guide for construction professionals. London: Witherby \& Co.

2. Bunni, G.N. (2003). Risk and insurance in construction. London-New York: Spon Press.

3. Burtonshaw-Gunn, S.A. (2009). Risk and Financial Management in Construction. Farnham: Gower Publishing.

4. Drucker, P.F. (1964). Managing for Results: Economic Tasks and Risk-taking Decisions. London: Heinemann.

5. Edwards, J.P., and Bowen, A.P. (2005). Risk Management in Project Organizations. Oxford: Elsevier.

6. Edwards, L. (1995). Practical risk management in the construction industry. London: Thomas Telford.

7. Flanagan, R., and Norman, G. (1993). Risk management in construction. Oxford: Blackwell Publishing.

8. Glavinich, E.T. (2008). Contractor's Guide to Greek Building Construction: Management, Project delivery, documentation and risk reduction. Hoboken: John Wiley \& Sons.

9. Godfrey, S.P., and Halcrow, W. (1996). Control of Risk: A Guide to the Systematic Management of Risk from Construction. London: Construction Industry Research and Information Association.

10. Hoseini, E., Hertogh, M., and Bosh-Rekveldt, M. (2019). Developing a generic risk maturity model (GRMM) for evaluating risk management in construction projects. Journal of Risk Research, 1-21. Retrieved from https://www.tandfonline.com/doi/pdf/ 10.1080/13669877.2019.1646309?needAccess=true, 05.09.2020.

11. Kosecki, A., and Madyda, A. (1996). Kierowanie ryzykiem w przedsiębiorstwie budowlanym. In Technologia w budownictwie - teoria i praktyka. Konferencja NaukowoTechniczna (pp. 76-84). Wrocław-Polanica Zdrój: Instytut Budownictwa Politechniki Wrocławskiej, Towarzystwo Naukowe Inżynierii Procesów Budowlanych.

12. Kosmalski, S., and Myrczek, J. (2019). Zarzadzanie ryzykiem w procesie budowy gazociagu przesyłowego. Warszawa: Difin. 
13. Loosemore, M., Raftery, J., Reilly, Ch., and Higgon, D. (2006). Risk Management in Projects. London-New York: Taylor \& Francis Group.

14. Myrczek, J., and Tworek, P. (2019). From the research on risk management in Polish construction enterprises. In: K. Wilde, M. Niedostatkiewicz (Eds.). 64 Scientific Conference of the Committee for Civil Engineering of the Polish Academy of Sciences and the Science Committee of the Polish Association of Civil Engineers (PZITB) (pp. 1-8). Krynica: MATEC Web of Conferences. doi: https://doi.org/10.1051/matecconf/ 201926207009.

15. Myrczek, J., Juraszek, J., and Tworek, P. (2020). Risk Management Analysis in Construction Enterprises in Selected Regions in Poland. Technical Transactions, 117(1), 1-13. doi: https://doi.org/10.37705/TechTrans/e2020025.

16. Myrczek, J., Sadlik-Lenczewska, M., and Tworek, P. (2015). Wybrane problemy zarządzania ryzykiem w działalności przedsiębiorstw budowlanych. In: M. Szajt (Ed.), Zarządzanie (pp. 127-136). Częstochowa: Politechnika Częstochowska.

17. Palmer, J.W., Maloney, J.M., and Heffron, L.J. (1996). Construction insurance, bonding, and risk management. New York: McGraw-Hill.

18. Sawczuk, B. (2004). Risk Avoidance for the Building Team. London: E \& FN Spon.

19. Serpell, A., Ferrada, X., and Rubio, L.N. (2017). Fostering the effective usage of risk management in construction. Journal of Civil Engineering and Management, 23(7), 858-867. doi: https://doi.org/10.3846/13923730.2017.1321578.

20. Smith, N.J., Merna, T., and Jobling, P. (2006). Managing risk in construction projects. Oxford: Blackwell Publishing.

21. Tworek, P. (2012). Excerpts from the scientific research on risk conducted among the largest Polish contractors. Journal of Management and Finance, 10(1), 113-121.

22. Tworek, P. (2013). Reakcja na ryzyko $w$ działalności przedsiębiorstwa budowlanomontażowego. Warszawa: Difin.

23. Wang, Q.S., Dulaimi, F.M., and Aguria, Y.M. (2004). Risk management framework for construction projects in developing countries. Construction Management and Economics, 22(3), 237-252. doi: https://doi.org/10.1080/0144619032000124689.

24. Young, C.P., and Tippins, C.S. (2001). Managing Business Risk: An Organization-Wide Approach to Risk Management. New York: American Management Association.

25. Zuo, F., and Zhang, K. (2018). Selection of risk response actions with consideration of secondary risks. International Journal of Project Management, 36(2), 241-254. 